\title{
افتتاصية العددد
}

تتشرف كلية الدراسات الاقتصادية والعلوم السياسية بجامعة الإسكندرية أن تقدم للباحثين والقراء العرب العدد الثالث من مجلتها العلمية. ويضم العدد ست دراسات هامة ومتتوعة؛ ثلاث منها

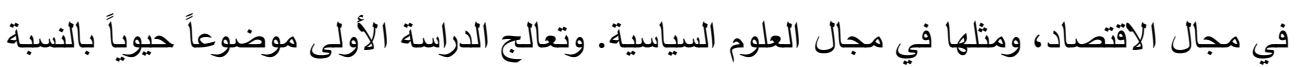

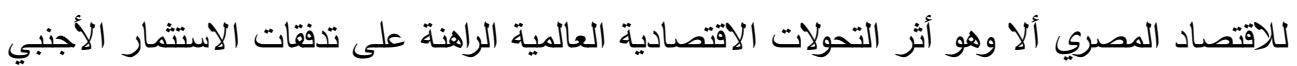

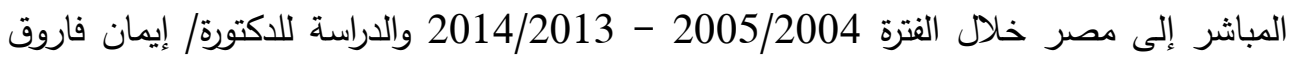
السيد الحداد. أما الدراسة الثانية وهي للباحث/ وليد حسن قاسم فتتعلق بتحليل موضوع نظري يتعلق

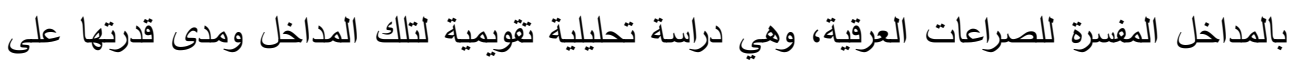

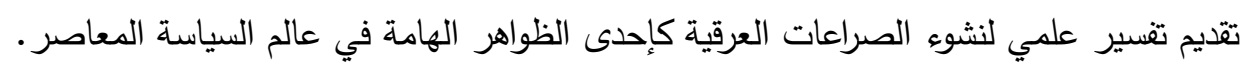

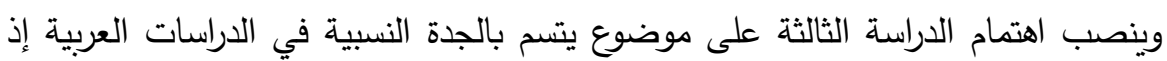
تتدر الدراسات التي تطرقت إليه ألا وهو موضوع: الديمقراطية داخل الأحزاب في النظم اللييرالية

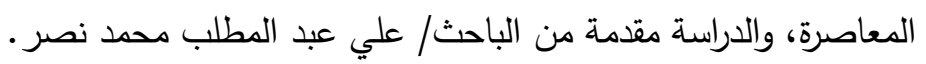

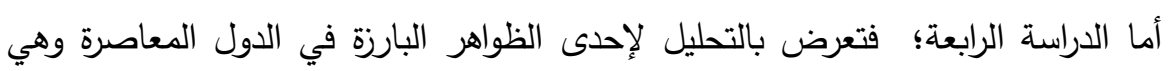
ظاهرة الإدارة الإكترونية في رحاب الحكومة الإكترونية، والدراسة من إعداد الباحثة/ نادية إبراهيم

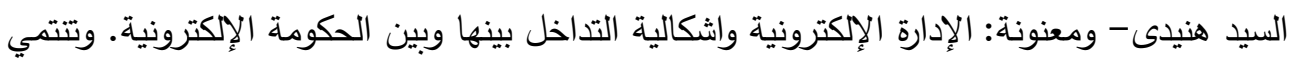

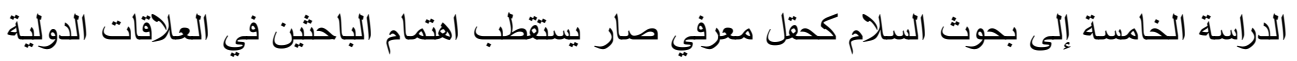

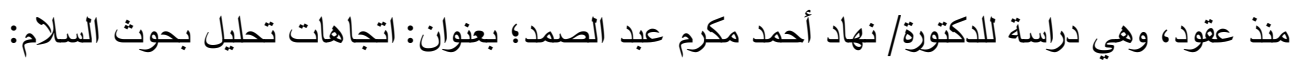
دراسة مسحية في الأدبيات المعاصرة.

ثم تأتي الدراسة السادسة والأخيرة في هذا العدد للاكتور / محمد سيد عابد وهي دراسة باللغة الإنجليزية بعنوان: " Is inflation mean-reverting? Evidence from Egypt during 2016-1974" ، وتعالج القضية التي تحظى باهتمام كافة دول العالم دون استثناء ألا وهي ظاهرة

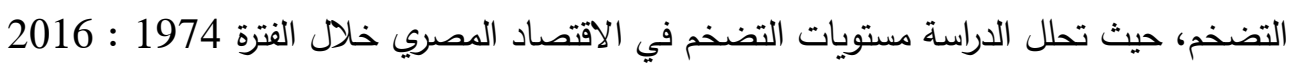

لتجيب عن تساؤل محوري يتعلق بمدى استقرار معدلات التضخم وعودتها إلى متوسطها العام.

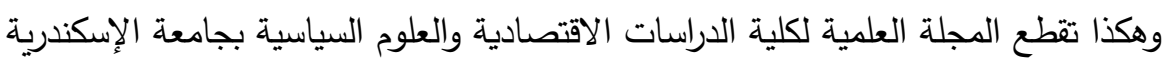

الثوط الثالث نحو الريادة بين نظيراتها المتخصصة في مجالات الاقتصاد والعلوم السياسية في

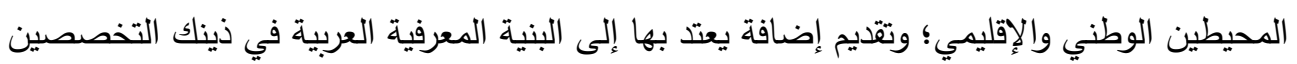

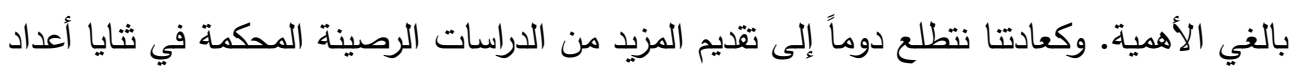
قادمة، والله من وراء القصد.

رئيس التحرير 